\title{
Neonatal mortality in dogs in a veterinary hospital in Brazil
}

\author{
Mortalidade neonatal em cães em um hospital veterinário no Brasil \\ Mortalidad Neonatal en Perros en un hospital veterinario en Brasil
}

Cristiane Ferreira da Luz Brun ORCID: https://orcid.org/0000-0001-6697-1529 Faculdade Itapiranga, Brazil E-mail:crisflbrun@yahoo.com.br

Luan Vinicius Tezzei Maia

ORCID: https://orcid.org/0000-0003-0704-8691 Universidade Paranaense, Brazil E-mail:luantezzei@hotmail.com

Jaqueline Lustosa Rodrigues Camapum ORCID: https://orcid.org/0000-0001-8993-0391 Médica veterinária autônoma, Brazil

E-mail: jaqueline22_lustosa@hotmail.com Natalie Bertelis Merlini ORCID: https://orcid.org/0000-0002-0329-6594 Universidade Paranaense, Brazil

E-mail: nataliemerlini@prof.unipar.br

Salviano Tramontim Belettini ORCID: https://orcid.org/0000-0002-0600-5836 Universidade Paranaense, Brazil E-mail: salviano@prof.unipar.br

Filipi Alexandre do Nascimento Silva ORCID: https://orcid.org/0000-0002-3503-3852 Médico veterinário autônomo, Brazil E-mail: filipialexandrevet@gmail.com Marcelo Campos Rodrigues ORCID: https://orcid.org/0000-0001-8704-1056 Universidade Federal do Piauí, Brazil E-mail: olecramsopmac@gmail.com

Pollyana Linhares Sala

ORCID: https://orcid.org/0000-0002-6080-8234 Médica Veterinária autônoma, Brazil E-mail: pollysala@hotmail.com João Moreira da Costa Neto

ORCID: https://orcid.org/0000-0003-2679-792X Universidade Federal da Bahia, Brazil E-mail: mcn@ufba.br

Dérick De Almeida Marchi

ORCID: https://orcid.org/0000-0003-3504-6466 Universidade Paranaense, Brazil E-mail: derick.marchi@edu.unipar.br Talita Bianchin Borges ORCID: https://orcid.org/0000-0001-7385-9615 Universidade Paranaense, Brazil E-mail: t-borges@hotmail.com.

Arthur Venicius Sbaraini Leitzke ORCID: https://orcid.org/0000-0001-7554-9055

Médico Veterinário autônomo, Brazil

E-mail: arthurleitzke@hotmail.com

Giuliana Cavalcanti dos Santos ORCID: https://orcid.org/0000-0002-1870-1089

Universidade Paranaense, Brazil E-mail: giuliana.santos@edu.unipar.br Ana Maria Quessada ORCID: https://orcid.org/0000-0003-0577-0808

Universidade Paranaense, Brazil E-mail: mariaquessada@prof.unipar.br 


\title{
Resumo
}

A neonatologia (área que estuda o recém-nascido) é uma especialidade ainda pouco explorada na clínica médica de cães. Dessa maneira, a mortalidade neonatal é alta e também há carência de dados sobre o tema no Brasil. O objetivo deste trabalho foi registrar a taxa de mortalidade neonatal de cães em um Hospital Veterinário Universitário. Foram analisados 69 filhotes caninos (oriundos de 17 fêmeas) recém-nascidos (35 fêmeas e 34 machos). A maior parte das fêmeas estavam em trabalho de parto $(94 \%$; 16/17) e apresentaram parto distócico. Do total de filhotes (69), 30 sobreviveram nas primeiras 24 horas $(43,47 \%$; 30/69). Portanto a mortalidade neonatal foi de 56,52\% (39/69), sendo considerada uma taxa muito elevada, provavelmente devido à hipóxia que é comum em neonatos oriundos de partos distócicos. Diante do exposto, conclui-se que a reprodução assistida e exames pré-natais devem ser incentivados para a redução da mortalidade neonatal em cães.

Palavras-chave: Neonatologia; Cão; Recém-nascido; Parto distócico; Óbito.

\begin{abstract}
Neonatology (the study of newborns) remains a little-explored specialty in medical clinics treating dogs. Therefore, neonatal mortality in dogs is high, and there is a lack of data on the subject in Brazil. The objective of this study was to record the neonatal mortality rate in dogs being treated at a Teaching Veterinary Hospital. We analyzed 69 (35 female and 34 male) newborn puppies born to 17 female dogs. The majority of the female dogs $(94 \% ; 16 / 17)$ and had dystocic parturition. Of the 69 puppies, only $30(43.47 \%)$ survived the first 24 hours after birth. Based on these numbers, the neonatal mortality was considerably high at $56.52 \%$ (39/69), probably due to hypoxia that is known to be common in neonates with dystocic births. Given the above, it is concluded that assisted reproduction and prenatal examinations should be encouraged to reduce neonatal mortality in dogs.
\end{abstract}

Keywords: Neonatology; Dog; Newborn; Dystocic parturition; Death.

\section{Resumen}

La neonatología (estudio o área de recién nacidos) es una especialización un poco explorada en la clínica médica canina. Por lo tanto, alta mortalidad neonatal y también falta de datos sobre o no Brasil. El objetivo de este trabajo fue registrar la tasa de mortalidad neonatal de perros en un Hospital Veterinario Universitario. Se analizaron 69 cachorros caninos (provenientes de 17 hembras) recién nacidos (35 hembras y 34 machos). La mayoría de las mujeres estaban en trabajo de parto $(94 \% ; 16 / 17)$ y presentaron trabajo de parto distócico. Número total de cachorros (69), 30 sobrevivieron las primeras 24 horas $(43,47 \%$; 30/69). Por tanto, la mortalidad neonatal fue del 56,52\% (39/69), considerándose una tasa muy alta, probablemente debido a la hipoxia que es común en los neonatos originada en partos distócicos. Durante la exposición, se concluyó que se debe fomentar la reproducción asistida y los exámenes prenatales para reducir la mortalidad neonatal en los niños.

Palabras clave: Neonatología; Perro; Recién nacido; Parto distócico; Muerte.

\section{Introduction}

The neonatal period in dogs and cats corresponds to 30 days and is characterized by a critical period of adaptation of organic systems to the new environment. (Lourenço; Machado, 2013).

Neonatology (the study of newborns) remains a little-explored specialty in medical clinics treating dogs and cats (Domingos et al., 2008). Therefore, neonatal mortality among these animals is high (Domingos et al., 2008; Mila et al., 2015), and the knowledge deficiency in this area is quite evident, especially in Brazil (Domingos et al., 2008). One of the most important factors involved in mortality is the nutritional factor (Mila et al., 2015).

The economic value of purebred puppies as well as the increased emotional involvement of guardians with their pets in the parturition process resulted in increased interest in improving the survival of puppies (Veronesi et al., 2009). Knowledge of physiology, vigor assessment and rapid intervention, with regard to resuscitation, are essential to reduce mortality (Lourenço; Machado, 2013).

The most delicate phase of canine neonates occurs soon after birth (Gropetti et al., 2015). In the first 24 hours, the puppy loses about $10 \%$ of its weight, due to the dehydration that it suffers from losing fetal envelopes and liquids. Therefore, it is important for the veterinarian to properly assess the parturient in order to select the best approach (normal delivery or cesarean). The newborn needs to be examined by a qualified professional to recognize the neonatal patient who suffers from some pathological alterations (Domingos et al., 2008). 
In the first three weeks of life, puppies are in the habit of eating and sleeping, receiving adequate amounts and qualities of breast milk as long as the mother is healthy and well-nourished to supply the puppies' food needs (Domingos et al., 2008)

If the newborn does not gain weight, due to difficulty in breastfeeding or reduced mother's milk in the first two weeks of life, artificial feeding is recommended, so that death does not occur (Barreto, 2003; Domingos et al., 2008).

Canine neonatal mortality in the first weeks of life reaches percentages close to $30 \%$, the inability to carry out the correct clinical analysis and the deficit in technical-scientific knowledge are the main reasons for the high rates reported (Silva et al., 2008).

Weight is one of the most important characteristics of very young animals (Domingos et al., 2008; Gropetti et al., 2015) and must be carefully recorded at birth. This conduct allows the identification of patients at risk, enabling appropriate measures to be taken to increase the animals' chances of survival (Domingos et al., 2008).

Low birth weight is accompanied by immature physiological processes that can lead to adaptive impairment after birth , often associated with inadequate production or release of pulmonary surfactant which may predispose neonatal mortality (Lawler, 2008 ). Therefore, low newborn weight should be considered as a prognostic factor for survival within the first 24 hours of birth, and special assistance should be given to low weight newborns to reduce perinatal mortality (Dodamani et al., 2017).

In studies with canine neonates, it was observed that birth weight was influenced by the size of the litter within a racial category and, in large litters, the weight of the neonates was $25 \%$ below the normal weight of the breed (Mila et al., 2015). In addition, the weight of newborn dogs is directly related to the weight of the pregnant female, of the fetal envelopes and liquids (Martin et al., 2005).

The knowledge of the peculiarities inherent to this critical period of the newborn's physiological adaptation is essential for the decline in the high rates of fetal and neonatal mortality. As well as the advances observed in reproductive biotechnology, veterinary neonatology represents an area in rapid development, full of possibilities (Lourenço;Machado, 2013).

The objective of this work was to register the mortality rate of newborn dogs in a veterinary service, since these numbers are scarce in the Brazilian literature.

\section{Material and Methods}

The procedures performed during the experiment were approved by the Animal Experimentation Ethics Committee of the institution where it was conducted (protocol number 272/16).

Prospective study was carried out from January 2017 to July 2018 on neonatal mortality of dogs at a University Veterinary Hospital, considering that the canine mortality rate is poorly documented in the literature (Ogbu et al., 2016). As a data collection instrument, simple observation was used. The research was qualitative/quantitative with descriptive data, analyzed by an inductive process (Perreira et al., 2018).

We analyzed 69 newborn canine puppies (35 females and 34 males), of which 39 were stillborn (total between females and males). Such neonates came from 17 female dogs who were routinely attended to at a Teaching Veterinary Hospital (TVH).

The parturients were weighed before giving birth and after giving birth. According to their weight, the bitches were divided into small size (weight equal to or less than $9 \mathrm{~kg}$ ), medium size (weight between $9.1 \mathrm{~kg}$ and $23 \mathrm{~kg}$ ) and large size (weight between $23.1 \mathrm{~kg}$ to $45 \mathrm{~kg}$ ) (Goldston; Hoskins, 1999).

After the birth of the puppies, the number of puppies, the type of birth (normal or dystocic) and the number of animals born alive were recorded. All newborns were identified by gender and weighed on a precision digital scale, obtaining the body mass. Puppies were classified into three groups: Group I: small dogs (0 to $199 \mathrm{~g}$ ); Group II: medium-sized dogs (weight ranging from 200 to 299 g); Group III: large dogs (over 300 g) (Barreto 2003). 
Descriptive analysis of the study variables was performed by determining the mean and standard deviation. In addition, the association between the variables weight of the mother $(n=17)$ and the weight of the newborn $(n=69)$ was verified using the Spearman correlation test. For all tests, a significance level of $1 \%$ was considered.

\section{Results and Discussion}

Almost all bitches $(94 \% ; 16 / 17)$ had dystocic birth. It was not possible to diagnose the cause of dystocia in the canine females included in the study, but the majority of canine dystocia (approximately $75 \%$ ) originates from primary uterine inertia (Smith, 2006). Primary uterine inertia is the inability of the uterus to develop and maintain the necessary contractions for the expulsion of the fetus (Smith, 2006). It is likely that this etiology was involved in dystocia in the study bitches.

All bitches that presented dystocia underwent radical cesarean section (en bloc) (Traas, 2008). This occurred at the request of the owners who wanted to castrate the females. Such conduct is common in Brazilian services (Rodrigues et al., 2018).

The parturients had the following body mass values (mean \pm standard deviation) pre and postpartum, respectively, by group: Group I: $4.23 \pm 2.21 \mathrm{~kg}$ and $3.8 \pm 2.06 \mathrm{~kg}$, with $0.43 \mathrm{~kg}$ of fetal membranes; Group II: $13.96 \pm 3.55 \mathrm{~kg}$ and $12.72 \pm 3.93$ $\mathrm{kg}$, with $1.24 \mathrm{~kg}$ of fetal membranes; and Group III: $34.25 \pm 12.37 \mathrm{~kg}$ and $31.9 \pm 11.17 \mathrm{~kg}$, with $2.35 \mathrm{~kg}$ of fetal membranes. These results were similar to those observed in another study involving female dogs with similar characteristics (Martin et al., 2005).

The birth weight of the offspring ( $n=69)$ reached a total average of $204.58 \pm 110.24$ grams. In group I puppies ( $n=43$ ) the general mean body mass and standard deviation was $142.9 \pm 39.1 \mathrm{~g}$. The animals in group II ( $\mathrm{n}=16)$ had an overall mean and standard deviation of $240.15 \pm 31.90 \mathrm{~g}$. In group III puppies $(\mathrm{n}=10)$ the mean body mass with standard deviation was $412 \pm 119.9$ g. (Table 1). Such data are similar to those observed in the literature that registers birth weight of puppies in Brazil (Martin et al., 2005).

Table 1: Mean \pm standard deviation of weight (grams) of small (Group I), medium (Group II), and large size (Group III) canine neonates $(n=69$, live and stillborn) born to 17 female dogs treated in a University Veterinary Hospital.

\begin{tabular}{lcccccc}
\hline & \multicolumn{2}{c}{ Group I (up to $199 \mathrm{~g})$} & \multicolumn{2}{c}{ Group II (200-399 g) } & \multicolumn{2}{c}{ Group III (over 300 g) } \\
& $\mathrm{N}=43$ & & \multicolumn{2}{c}{$\mathrm{N}=16$} & \multicolumn{2}{c}{$\mathrm{N}=10$} \\
\hline & Alive & Stillborn & Alive & Stillborn & Alive & Stillborn \\
\hline Weight $(\mathrm{g})$ & 152.88 & 136.22 & 235 & 243.24 & 466 & 333 \\
& \pm 39.9 & \pm 39.04 & \pm 33.1 & \pm 32.6 & \pm 131.1 & \pm 17.4 \\
\hline
\end{tabular}

Source: Own Research.

Spearman's correlation test showed a positive correlation between the weight of the mother before delivery and the weight of the newborns ( $r s=0.424$, with $\mathrm{p}<0.01$ ) (Table 2), showing that the weight of the mother influences in $17,98 \%$ the weight of newborns. This result was expected since the weight of newborn dogs is directly related to the mother's weight (Martin et al., 2005). 
Table 2: Spearman's correlation coefficient between the prepartum weight of parturient bitches treated at a university veterinary hospital $(n=17)$ and the weight of their newborn puppies $(n=69)$.

\begin{tabular}{lcc}
\hline & $\begin{array}{c}\text { Weight of parturient bitch } \\
\text { (grams) }\end{array}$ & $\begin{array}{c}\text { Weight of newborn } \\
\text { (grams) }\end{array}$ \\
\hline Weight of parturient bitch (grams) & 1.000 & 0.424 \\
Weight of newborn (grams) & -- & 1.000 \\
\hline
\end{tabular}

Statistical significance evaluated at $\mathrm{P}=0.01$

Source: Own Research

Regarding the sex of the newborns, $50.72 \%$ of females (35/69) and $49.28 \%$ of males (34/69) were obtained. This data reflects the fact that the birth of males and females is balanced in the canine species (Vassalo et al., 2015).

Of the total number of offspring (69), only 30 were alive in the first 24 hours $(43.47 \%$; 30/69). Therefore, neonatal mortality in the present study was $56.52 \%$ (39/69) in the follow-up period (24 hours). This mortality rate is very high compared to the literature, in which it is observed that the canine neonatal mortality rate is around 20 to $30 \%$ (Konde et al., 2015).

However, the canine mortality rate is poorly documented in the literature (Ogbu et al., 2016). In the Brazilian literature, only one article was found reporting a neonatal mortality rate in dogs, which was around 15\% in the first seven days ( Vassalo et al., 2015). This high rate recorded here $(56.52 \%)$ is probably related to the fact that most female dogs included in the study had dystocic birth, and the correct approach was not performed during home birth. Dystocia is one of the leading causes of neonatal death in dogs (Konde et al., 2015; Ogbu et al., 2016; Souza et al., 2017). Perinatal hypoxia associated with dystocia is considered the leading non-infectious cause of perinatal mortality, with $90 \%$ of deaths occurring within 48 hours of birth (Munnich; Kunchensmeister, 2014).

Fetal or neonatal stress increases the possibility of sepsis, which explains the high mortality rate of puppies born in dystocic births. In addition, the prolongation of a dystocic birth causes direct fetal alterations represented by stress. This phenomenon generates some consequences such as fetal tachycardia or cardiac arrest, reduction or absence of fetal movement, fetal hypoxia due to compromised placental circulation and metabolic acidosis resulting from the decrease in blood oxygenation resulting in the production of lactic acid (Davidson, 2003).

Furthermore, it should be emphasized that most studies on canine neonatal mortality refer to other countries and purebred animals (Konde et al., 2015; Ogbu et al., 2016; Souza et al., 2017). The females in the research reported here were, for the most part, of no defined breed.

The main characteristics that make newborns more vulnerable to illnesses and death are related to deficient thermoregulation, risk of dehydration and hypoglycemia (neonatal triad), in addition to immunological immaturity (Munnich; Kunchensmeister, 2014).

It was not possible to determine the causes of death of the neonates in the present study. This occurred because the identification of the etiology of neonatal death depends on necropsy, histopathological examinations and investigation of infectious agents in tissues (Souza et al., 2017). However, such exams are expensive and the tutors of the dogs in the study do not have the financial conditions to carry out such exams.

It is important to emphasize that all bitches included in the study underwent en bloc cesarean section, and the uterus was opened after removal from the abdominal cavity (Traas, 2008). Although the maneuver was quick, the fact of removing the fetuses outside the abdominal cavity may have contributed to increase neonatal mortality. These newborns may have hypoxia, and low oxygenation may contribute to neonatal death in dogs (Davidson, 2003; Munnich; Kunchensmeister , 2014). The option to remove the fetuses outside the abdominal cavity is due to the possibility of contamination of the abdominal cavity by fetal fluids, which can lead to peritonitis (Humm et al., 2010). 


\section{Conclusion}

The neonatal mortality recorded in the present study was quite high, probably because most deliveries were dystocic. Prenatal examinations and assisted reproduction should be encouraged to reduce dystocia and consequently, mortality.

In the future the expectation is that guardians become more responsible in relation to the care of their animals before, during and after pregnancy, thus avoiding and preventing problems during pregnancy. In addition, castration of animals without commercial reproductive interest should be encouraged.

\section{References}

Barreto, C. S. (2003). Avaliação de filhotes caninos. 19f. Monografia (especialização) - Faculdade de Medicina Veterinária e Zootecnia - Universidade de São Paulo.

Davidson, A. P. (2003). Approaches to reducing neonatal mortality in dogs. In P.W. Concannon, G. England, J. Verstegen \& C. Linde-Forsberg (Eds.). Recent Advances in Small Animal Reproduction. Ithaca, NY: International Veterinary Information Service. https://www.researchgate.net/profile/ Autumn_Davidson/publication/267937790_Approaches_to_Reducing_Neonatal_Mortality_in_Dogs_19-Mar-2003/links/55b184800 8aed621ddfd558 2/Appro ach es-to-Reducing-Neonatal-Mortality-in-Dogs-19-Mar-2003.pdf

Dodamani, M. S., Krishnaswamy, A., Honnappagol, S. S., Yathiraj, S., Narayanswamy, M., Sudha, G., Chandrashekarmurthy, V. (2017). Birth weight, litter size, sex ratio and neonatal mortality in pure bred mudhol hounds, International Journal of Science, Environment and Technology. 6(4), $2307-2317$.

Domingos, T. C. S. Rocha, A. A; Cunha, I. C. N. (2008). Cuidados básicos com a gestante e o neonato canino e felino: revisão de literatura. Jornal Brasileiro de Ciência Animal. 1(2), 94-120.

Goldston, R. T., \& Hoskins J. D. (1999) Geriatria e gerontologia em cães e gatos. (2a ed.), Roca, 551.

Groppetti, D., Martino, P. A., Ravasio, G., Bronzo, V., \& Pecile, A. (2015). Prognostic potential of amniotic fluid analysis at birth on canine neonatal out comes. The Veterinary Journal, 206(3), 423-425.

Konde, A. M. (2015). Puppy Morbidity and Mortality among Breeding Kennels in Nairobi, Kenya. Jacobs Journal of Veterinary Science and Research. 1(4), 19.

Lawler, D. F. (2008). Neonatal and pediatric care of the puppy and kitten. Theriogenology. 70(3), 384-392.

Lourenço, M. L. G., \& Machado, L. H. A. (2013) Características do período de transição fetal-neonatal e particularidades fisiológicas do neonato canino. Revista Brasileira de Reprodução Animal. 37(4), 303-308.

Martin, I., Prestes, N. C., Ferreira, J. C. P., Lopes, M. D., \& Trinca, L. A. (2005) Estudo da correlação entre o peso dos neonatos, envoltórios e líquidos fetais com o peso total de cadelas gestantes submetidas à cesariana. Ars Veterinaria. 21(2), 281-286.

Mila, H; Grellet, A., Feugier, A., \& Chastant-maillard, S. (2015). Differential impact of birth weight and early grow thon neonatal mortality in puppies. Journal of animal science. 93(9), 4436-4442.

Munnich, A., \& Kuchenmeister, U. (2014). Causes, Diagnosis and Therapy of Common Diseases in Neonatal Puppies in the First Days of Life: Cornerstones of Practical Approach. Reproduction in Domestic Animals. 49(2), 64-74.

Ogbu, UC K. I., Ochai, S. O., Danladi, M. M. A., Abdulateef, M. H., Agwu, E. O., \& Gyengdeng, J. G. (2016). Are view of Neonatal mortality in Dogs. International Journal of Life Sciences. 4(4), 451-460.

Pereira, A. S., Shitsuka, D. M., Parreira, F. J., \& Shitsuka, R. (2018). Metodologia da pesquisa científica. UFSM. https://repositorio.ufsm.br/bitstre am/handle/1/15824/Lic_Computacao_MetodologiaPesquisa-Cientifica.pdf?sequence=1.

Rodrigues, N. M. et al. (2018). Classificação anestésica do estado físico e mortalidade anestésico-cirúrgica em cães. Arquivo Brasileiro de Medicina Veterinária e Zootecnia. 70(3), 704-712.

Silva, C. G. et al. (2008). Avaliação clínica neonatal por escore Ápgar e temperatura corpórea em diferentes condições obstétricas na espécie canina. Revista Portuguesa de Ciência Veterinária. 103(567-568),165-170.

Smith, F. O. (2006). Canine Pyometra. Theriogenology. 66(3), 610-612.

Souza, T. D., Mol, J. P. S., Paixão, T. A., \& Santos, R. L. (2017) Mortalidade fetal e neonatal canina: etiologia e diagnóstico. Revista Brasileira de Reprodução Animal. 40(2), 639-649.

Vassalo, F. G., Simões, C. R. B., Sudano, M. J., Prestes, N. C., Lopes, M. D., Chiacchio, S. B., \& Lourenço, M. L. G. (2015). Topics in the routine assessment fo newborn puppy viability. Topics in Companion Animal Medicine.30, 16-21.

Veronesi, M. C., Panzani, S., Faustini, M., \& Rota, A. (2009). An Apgar scoring system for routine assessment of new born puppy viability and short-term survival prognosis. Theriogenology. 72(3), 401-407.

Traas, A. M. Surgical management of canine and feline dystocia. Theriogenology. 70(3) 337-342. 